\title{
PEMANFAATAN MOODLE PADA IDENTIFIKASI KENDALA DALAM SOAL READING DENGAN FORMAT TES TOEIC
}

\author{
Satriya Bayu Aji ${ }^{(1)}$, Condra Antoni ${ }^{(2)}$ \\ Jurusan Teknik Informatika, Politeknik Negeri Batam \\ Jl.Ahmad Yani, Batam Centre, Batam 2946I, Indonesia \\ Email: (I) satriya@polibatam.ac.id, (2)_condra@polibatam.ac.id,
}

\begin{abstract}
Abstrak
Sebagian besar peserta tes TOEIC yang mendapat skor rendah belum terbiasa dengan format tes tersebut. Penelitian ini bertujuan untuk mengidentifikasi masalah yang berpotensi menjadi hambatan dalam Reading Section tes TOEIC. Data penelitian ini berasal dari hasil ujian akhir semester Bahasa Inggris I pada semester genap tahun ajaran 2017/2018 serta ujian tengah semester dan ujian akhir semester Bahasa Inggris II pada semester gasal tahun ajaran 2018/2019 di Politeknik Negeri Batam. Seluruh ujian ini dilakukan secara daring dengan memanfaatkan e-learning berbasis Moodle. Data terdiri dari soal-soal dengan persentase jawaban benar rendah. Analisis dilakukan dengan cara mengklasifikasikan soalsoal tersebut ke dalam lima kemampuan yang dibutuhkan dalam Reading Section (kosakata, tata bahasa, pencarian detail, penarikan kesimpulan, dan hubungan antarkalimat). Berdasarkan analisis, dapat diamati bahwa hambatan terbesar datang dari aspek tata bahasa. Di sisi lain, hampir tidak ada masalah pada aspek pencarian detail. Ini berarti siswa masih menganggap Reading Section tes TOEIC tidak memerlukan perhatian khusus.
\end{abstract}

Kata kunci: TOEIC, Reading Section, Moodle

\begin{abstract}
Most TOEIC test takers who score low are unfamiliar with the format of the test. This study aims to identify the problems that will likely become obstacles in the Reading Section of the TOEIC test. The data come from the results of the English I online final exam in the second term of 2017/2018 as well as the English II online mid-term and final exam in the first term of 2018/2019, all of which were held in Politeknik Negeri Batam. The exams are part of Moodle-based e-learning courses. The data consist of questions which has low percentage of correct answers. The analysis was done by classifying the questions based on the five abilities measured in the Reading Section (vocabulary, grammar, specific information, inference, and connection). Based on the analysis, it can be observed that the biggest challenge comes from grammar, while the search for specific information poses little to no problem at all. It means the students still consider Reading Section of TOEIC test requires no special attention.
\end{abstract}

Keywords: TOEIC, Reading Section, Moodle 


\section{PENDAHULUAN}

Diperlukan kerja keras baik dari siswa maupun pengajar untuk meningkatkan skor TOEIC. Darmaliana dan Yeny (2016: 25) berpendapat bahwa hasil tes dipengaruhi efek washback. Untuk itu, diperlukan penyeimbangan antara pendekatan yang berpusat pada pengajar dan yang berpusat pada siswa, penekanan pada kerja kelompok, penyuluhan mengenai manfaat tes TOEIC, dan pemberian motivasi. Terdapat hubungan linier antara motivasi belajar dan prestasi belajar (Sulisworo, et al, 2016:195). Siswa dengan motivasi belajar yang tinggi cenderung memperoleh hasil yang lebih baik, dan penerapan e-learning dapat meningkatkan motivasi belajar siswa. Hal ini terbukti dari hasil yang dicapai melalui metode blended learning, yang berbeda secara signifikan dibanding metode tatap muka. Metode blended learning cenderung memberikan hasil yang lebih baik dibanding dengan hanya tatap muka. Hal ini senada dengan pendapat Harahap (2015:96), berdasarkan hasil kuesioner, bahwa mahasiswa merasa memiliki pengetahuan baru mengenai kuis online, dan terlihat senang dalam melaksanakannya, walaupun hasil yang dicapai belum maksimal.

Selain blended learning, terdapat pula Adaptive e-Learning System (AES). Pada AES tampilan materi secara otomatis menyesuaikan diri dengan penggunanya. Penyesuaian dapat mencakup isi dan urutan materi. Penyesuaian ini diperlukan karena siswa memiliki perbedaan dalam tujuan, latar belakang, tingkat pengetahuan, dan kemampuan belajar. Salah satu metode dalam pengumpulan informasi mengenai tujuan, preferensi, dan pengetahuan adalah kuesioner. Surjono (2014: 90) menggunakan kuesioner untuk membagi siswa menjadi enam kelompok berdasarkan gaya belajarnya: Global-Visual, Global-Auditory, Global-Kinestetik, Sekuensial-Visual, Sekuensial-Auditory, dan Sekuensial-Kinestetik. Tampilan materi berbeda pada tiap kelompok tersebut.

Ketiga penelitian tersebut menggunakan Moodle sebagai basis dalam penerapan e-learning. Dari sini tampak bahwa salah satu keunggulan Moodle adalah kecepatan dan ketepatan respon yang dapat diperoleh pengguna, baik siswa maupun pengajar. Salah satu keuntungan yang didapat pengajar yaitu ketersediaan informasi mengenai performa siswa. Sebagai contoh, dalam pelaksanaan ujian online, dapat diidentifikasi butir-butir soal dengan tingkat persentase jawaban rendah. Dari sini, dapat ditelusuri tingkat pemahaman peserta terhadap suatu materi.

Guna menunjang proses analisis, setelah identifikasi perlu dilakukan klasifikasi butir soal. Berdasarkan studi pustaka dari 500 soal TOEIC yang berasal dari beberapa buku panduan dan kumpulan soal TOEIC (Fauziati, 2016:21), klasifikasi pola pertanyaan dan persentase pada butir soal Completion (Incomplete Sentence dan Text Completion) dan Error Recognition terdiri dari:

- vocabulary $(54.34 \%)$

- $\quad$ class of words $(15 \%)$

- verb tense $(11.33 \%)$

- determiner $(5.33 \%)$

- preposition (4\%)

- conjunction $(3.67 \%)$

- $\quad$ degree of comparison in adjective (3.33\%)

- conditional sentence (3\%)

Salah satu masalah dalam klasifikasi ini adalah adanya tumpang tindih, antara lain pada kelas kata verba karena infleksi verba berperan penting dalam soal yang berkaitan dengan tense. Selain itu, akan sulit mengklasifikasikan 
soal mengenai gerund karena memiliki fungsi yang lebih mirip nomina daripada verba meskipun bentuk dasarnya merupakan verba.

Klasifikasi pola pertanyaan juga dilakukan pada Reading Comprehension. Berdasarkan konteks, teks pada bagian ini meliputi General Business, Manufacturing, Finance and Budgeting, Offices, Personnel, Purchasing, Housing/corporate property, Travel, Dining out, Entertainment, dan Health. Klasifikasi ini tidak menyebutkan secara jelas kriteria yang digunakan dalam pengelompokan, serta pengaruh konteks tersebut terhadap strategi dalam mengerjakan soal. Lebih lanjut, soal pada bagian ini juga diklasifikasikan menjadi pertanyaan mengenai gagasan utama, informasi yang secara langsung dinyatakan, informasi yang tersirat, tujuan penulis, dan bagaimana penulis mengembangkan dan menyajikan bacaan. Jika ditinjau secara keseluruhan, dengan melihat klasifikasi pada bagian Incomplete Sentence, Text Completion, dan Error Recognition, klasifikasi ini menyiratkan pemisahan antara bentuk dan makna; seolah-olah, hanya makna yang berperan pada bagian Reading Comprehension. Namun, seperti telah diketahui, bentuk yang dipilih menentukan makna. Ditambah lagi, pemilihan dan pemilahan makna memberikan dampak pada pilihan-pilihan selanjutnya. Pada akhirnya, bentuk dan makna sulit dipisahkan (Sinclair, 1991: 7). Berdasarkan hal tersebut, penelitian ini akan mengidentifikasi kebermanfaatan klasifikasi pola pertanyaan tersebut melalui penggunaan e-learning berbasis Moodle dalam bentuk kuis daring.

\section{METODE}

Brown (2004: 489) mengklasifikasikan metode penelitian dalam linguistik terapan menjadi tiga kelompok: interpretif, survei, dan statistik berdasarkan letaknya dalam suatu rentang yang melibatkan tiga belas kriteria (tipe data, metode pengambilan data, metode analisis, dan lain-lain). Ketiga metode penelitian ini menaungi sebelas teknik penelitian. Penelitian ini menggunakan metode penelitian statistik dengan teknik deskriptif. Metode dan teknik penelitian yang digunakan memungkinkan penggunaan statistik sebagai dasar analisis yang ditunjang dengan interpretasi berupa deskripsi yang relevan terhadap suatu butir soal atau klasifikasi.

Data berasal dari hasil ujian akhir semester (UAS) bahasa Inggris I serta ujian tengah semester (UTS) dan UAS bahasa Inggris II mahasiswa Politeknik Negeri Batam. Data hasil UAS bahasa Inggris I terdiri dari hasil tes 314 mahasiswa, yang terdiri dari mahasiswa program studi D3 Teknik Elektronika (51), D3 Elektronika Manufaktur (15), D3 Akuntansi (58), D3 Teknik Geomatika (47), D3 Teknik Informatika (69), dan D4 Teknik Multimedia dan Jaringan (74). Data hasil UTS bahasa Inggris II terdiri dari hasil tes 235 mahasiswa, yang terdiri dari mahasiswa program studi D3 Teknik Elektronika (48), D3 Akuntansi (30), D3 Teknik Geomatika (19), D3 Teknik Informatika (60), dan D4 Teknik Multimedia dan Jaringan (78). Data hasil UAS bahasa Inggris II terdiri dari hasil tes 270 mahasiswa, yang terdiri dari mahasiswa program studi program studi D3 Teknik Elektronika (47), D3 Akuntansi (30), D3 Teknik Geomatika (32), D3 Teknik Informatika (81), dan D4 Teknik Multimedia dan Jaringan (80). Soal-soal dengan persentase jawaban benar di bawah nilai kuartil pertama digunakan sebagai data. Setelah itu, analisis dilakukan dengan mengelompokkannya berdasarkan kemampuan yang diukur (abilities measured) dalam Reading Section, yang berdasarkan Examinee Handbook for the Updated Version of the TOEIC Listening \& Reading Test terdiri dari kosa kata (vocabulary), tata bahasa (grammar), pencarian detail (specific information), penarikan kesimpulan (inference), dan hubungan antarkalimat (connecting information), untuk kemudian ditinjau dari pokok bahasan terkait.

Soal tes terdiri dari 200 soal yang terdiri dari dua bagian, listening dan reading, yang masing-masing terdiri dari 100 soal. Listening Section terdiri dari empat bagian: Photographs (10), Question-Response (30), Short 
Conversations (30), dan Short Talks (30). Reading Section terdiri dari 3 bagian: Incomplete Sentences (40), Text Completion (12), dan Reading Comprehension (48). Komposisi soal mengacu pada format yang berlaku hingga April 2018. Soal diambil dari Barron's TOEIC Test $\left(4^{\text {th }}\right.$ Edition) dan Complete Guide to the TOEIC Test: Student Book ( $3^{\text {rd }}$ Edition). Waktu pengerjaan soal secara keseluruhan 120 menit (45 menit untuk listening dan 75 menit untuk reading).

\section{HASIL DAN PEMBAHASAN}

\section{Tata Bahasa}

Dalam TOEIC score report tercantum persentase jawaban benar terkait lima kemampuan, masing-masing terkait listening dan reading. Lima kemampuan yang diukur dalam bagian reading yaitu kosa kata, tata bahasa, pencarian detail, penarikan kesimpulan, dan hubungan antarkalimat. Penguasaan tata bahasa terkait erat dengan bagian Incomplete Text (Part 5) dan Text Completion (Part 6). Berdasarkan hasil UTS dan UAS, pada Reading Section Part 5 dan 6 terdapat 14 konsep terkait tata bahasa dengan tingkat persentase jawaban benar yang rendah, yang terangkum dalam tabel 3-1.

\section{Tabel 3-1. Distribusi Frekuensi Jumlah Soal Berdasarkan Pokok Bahasan}

\begin{tabular}{|c|c|c|c|}
\hline Pokok Bahasan & UAS Bahasa Inggris I & UTS Bahasa Inggris II & UAS Bahasa Inggris II \\
\hline Present Tense (7) & $2(23,1-35,76 \%)$ & $1(50 \%)$ & $4(29,87-43,33 \%)$ \\
\hline Passive (5) & $2(35,44-43,04 \%)$ & $1(34,03 \%)$ & $2(35,78-46,67 \%)$ \\
\hline Participle (4) & $2(33,86-41,14 \%)$ & $1(44,96 \%)$ & $1(27,27 \%)$ \\
\hline Causative (4) & $1(41,14 \%)$ & $1(47,48 \%)$ & $2(34,44-39,26 \%)$ \\
\hline Part of Speech (4) & $2(25,95-35,44 \%)$ & $1(43,28 \%)$ & $1(37,78 \%)$ \\
\hline Conjunction (3) & - & $3(37,39-48,74 \%)$ & - \\
\hline Comparative (2) & $1(30,38 \%)$ & $1(50 \%)$ & - \\
\hline Phrasal Verb (2) & - & $1(35,29 \%)$ & $1(33,7 \%)$ \\
\hline Modals (1) & $1(31,33 \%)$ & - & - \\
\hline Imperative (1) & - & - & $1(47,41 \%)$ \\
\hline Past Tense (1) & - & $1(46,22 \%)$ & - \\
\hline Gerund (1) & - & - & $1(28,15 \%)$ \\
\hline Relative Pronoun (1) & $1(14,24 \%)$ & - & - \\
\hline Conditional (1) & - & - & $1(44,76 \%)$ \\
\hline
\end{tabular}

Keterangan: angka dalam kurung menunjukkan persentase siswa dengan jawaban benar

Dari klasifikasi Fauziati (2016:21) terkait tata bahasa, terdapat lima konsep yang masih menjadi kendala bagi siswa: verb tense, class of words, conjunction, degree of comparison in adjective, dan conditional sentence, sedangkan kesulitan terkait konsep determiner dan preposition tidak teridentifikasi. Pertanyaan terkait present tense memiliki beberapa variasi:

The last train to Hamburg (departs) at 10:30.

The ship provisions officer (buys) his supplies in large quantities.

We do not use any cleaning products or paints that (require) disposal as hazardous waste.

The electric company is (increasing) its rates by $25 \%$ next month, ... 
Ketiga kalimat tersebut belum berpredikat. Konstituen yang berfungsi sebagai predikat dalam bahasa Inggris adalah verba. Untuk membentuk kalimat yang gramatikal pada kalimat pertama, kedua, dan keempat diperlukan infleksi. Pada kalimat pertama dan kedua, karena melibatkan subjek tunggal, infleksi terjadi dalam bentuk penambahan suffix -s (simple present tense), sedangkan pada kalimat keempat penambahan suffix -ing (present continuous tense). Pada kalimat ketiga klausa that require disposal as hazardous waste merupakan relative clause. That sendiri merupakan subjek, yang mengacu pada frasa nomina any cleaning products or paints.

Terkait present tense, penggunaan konjungsi dapat melibatkan gapping. Subjek dalam klausa pertama dan kedua pada kalimat present tense berikut sama, sehingga hanya disebutkan di awal.

The receptionist receives packages and (holds) them until the proper department is notified.

The restaurant business (is) demanding and needs a constant influx of new talent.

Most employees drive to work and (enter) the building from the parking lot.

Pada tiap kalimat subjek pada klausa kedua (setelah kata hubung) sama dengan klausa sebelumnya (the receptionist, the restaurant business, dan most employees, masing-masing pada kalimat pertama, kedua, dan ketiga), sehingga perlu penyesuaian berupa infleksi penambahan suffix -s pada kalimat pertama dan -ing pada kalimat kedua. Pemilihan kata kerja bantu yang tepat pun masih menjadi kendala dalam pengerjaan soal. Contoh berikut terdiri dari dua klausa [the restaurant business (is) demanding dan ( $\varnothing:$ the restaurant business) needs a constant influx of new talent)]. Selain terdiri dari dua kalimat, di sini terdapat bentuk participle demanding sebagai predicative complement (Huddleston dan Pullum 2002: 53), dan subjek (the restaurant business) tunggal, sehingga diperlukan kata kerja bantu tunggal (is). Tense yang digunakan tampak pada verba dalam klausa kedua (needs). Selain tense, aspect juga berpengaruh terhadap infleksi verba. Infleksi juga terjadi pada verba dalam past tense, misal dalam kalimat "The clerk found the typographical error after the messenger (delivered) the proposal".

Terkait part of speech, kesulitan didominasi soal yang melibatkan kata sifat. Umumnya, kata sifat menjelaskan kata benda, baik yang berfungsi sebagai subjek maupun objek. Berikut beberapa contoh soal yang melibatkan kata sifat:

Information about employees' salaries is considered (confidential).

The hotel marketing director is quite (knowledgeable) about advertising in Europe.

I wouldn't bother using the lounge just for free refreshments and newspapers, "said Alistair Willows,

who makes (frequent) trips from Europe to South Africa for business.

Kata sifat dapat berfungsi sebagai predicative complement seperti dalam kalimat pertama dan kedua. Predicative complement dapat pula mengalami modifikasi, seperti dalam kalimat kedua, berupa penambahan adverb quite. Pada kalimat ketiga frequent merupakan modifier dari frasa nomina frequent trips. Pada kalimat ini kata sifat frequent bersama nomina trips membentuk frasa nomina frequent trips. Modifier dalam frasa nomina terkadang terletak di belakang inti (head), yang biasanya berupa frasa atau klausa, misal dalam kalimat "The scientific method is the (basis) of all scientific research." Penggunaan preposisi of menimbulkan recursion, yang berpotensi menghasilkan konstituen (dalam hal ini frasa nomina) yang terdiri dari banyak kata (misal, the scientific method is the basis of all scientific research of both natural and social science of...). Ditambah lagi, sebagian besar nomina dapat mengalami derivasi menjadi adjective, maupun sebaliknya.

Adjective juga berperan dalam konstruksi yang melibatkan perbandingan. Dalam membandingkan sesuatu, perbandingan dapat dilakukan dari sisi persamaan maupun perbedaannya. Untuk membandingkan suatu hal dari 
kesamaan, dalam bahasa Inggris digunakan konstruksi as ... as, seperti pada kalimat "The new bridge is not as picturesque (as) the old one, but it is much safer". Jika perbandingan ditinjau dari sisi perbedaan, dapat digunakan konstruksi comparative, seperti dalam contoh “Conference Room 2 is (pleasanter) than Conference Room l”. Pada contoh ini, infleksi pada adjective pleasant(er) bersifat inherent dan diperlukan untuk membentuk konstruksi comparative.

Pada contoh sebelumnya mengenai present tense telah disinggung mengenai gapping, yang di dalamnya melibatkan hubungan koordinasi antara dua klausa dengan kata hubung and. Namun, penggunaan kata hubung tidak selalu melibatkan gapping, seperti contoh berikut:

(Although) they were ordered, the brochures and business cards were never printed.

Naturally, we are not happy about paying more and more money for poor service. (Therefore), we are interested in learning more about Unity Health Care (UHC).

The operator does not remember receiving a fax from the Madrid office (or) from the Paris office.

Pada kalimat pertama tidak terjadi gapping akibat penggunaan pronomina (pronoun) they (yang mengacu pada subjek klausa inti). Di sini digunakan although untuk menunjukkan kontradiksi (contrast), sedangkan pada contoh kedua digunakan therefore untuk menunjukkan hubungan sebab akibat. Berbeda dengan contoh sebelumnya, pada kalimat pertama digunakan embedded clause, bukan koordinasi. Pada contoh ketiga, kata hubung or digunakan untuk menghubungkan frasa.

Terkait kalimat majemuk, konstruksi lain yang sering pula menjadi kendala adalah kalimat conditional. Umumnya, dikenal tiga bentuk kalimat conditional, yang salah satunya adalah past unreal conditional. Pada tipe ini digunakan past perfect tense, baik pada klausa bawahan (klausa dengan if) maupun klausa utama (klausa dengan past modal dan have), seperti dalam kalimat "If we had started earlier, we (would have met) the deadline".

Namun, selain kelima konsep tersebut (verb tense, class of words, conjunction, degree of comparison in adjective, dan conditional sentence) teridentifikasi delapan konsep yang tidak termasuk dalam kategori, yang meliputi konstruksi pasif, participle, causative, phrasal verb, modals, kalimat imperatif, gerund, dan relative pronoun. Meskipun tujuh yang pertama melibatkan verba, namun kurang tepat apabila ketujuh-tujuhnya dimasukkan dalam kategori-kategori tertentu, misal class of words atau verb tense, yang dapat menimbulkan tumpang tindih dengan kategori lain. Selain itu, relative pronoun juga kurang tepat jika dikategorikan sebagai conjunction, misalnya.

Voice dan tense merupakan konsep yang berbeda, sehingga tidak masuk dalam kategori verb tense. Selain tense dan aspect, dalam bahasa Inggris infleksi verba juga harus sesuai dengan voice, seperti dalam contoh berikut.

The ship's restaurant is (located) on the sun deck.

The itinerary (is filed) with the cruise list.

The airport taxes are (included) in the ticket price.

If this report is (sent) by overnight delivery, it will reach Milan by noon tomorrow.

As of this Friday passengers at Port Elizabeth Airport will no longer (be offered) free Internet service in the business travelers 'lounges.

Meskipun hanya kalimat terakhir yang menggunakan tense yang berbeda (future), seluruh inti pada frasa verba berbentuk past participle.

Terkait kelas kata verba, bentuk participle suatu verba dapat digunakan sebagai pengisi fungsi yang biasa dimiliki oleh adjective, baik dalam frasa verba maupun nomina. 
I' $\underline{m}$ really (pleased) that my health plan provider is paying for my gym membership.

Mr. Hatori was very (excited) when he got a promotion.

Mr. Selvas delivered the (sealed) bid to the client.

An (extended) training period will be instituted in July.

Selain sebagai predicative complement, seperti pada contoh pertama dan kedua, bentuk past participle juga dapat berperan sebagai konstituen dalam frasa nomina (seperti contoh ketiga dan keempat): Terdapat dua macam bentuk participle, past dan present. Namun, hanya bentuk past participle yang teridentifikasi masih sulit dipahami oleh peserta. Hal ini dapat disebabkan oleh kesamaan bentuk verba yang digunakan dengan bentuk yang digunakan dalam past tense (untuk regular verb), perfective aspect, atau kalimat pasif.

Secara umum, verba yang terletak setelah verba causative, dalam kalimat aktif, selalu menggunakan bentuk dasar atau to + infinitive. Beberapa verba causative yang umum dijumpai adalah have dan get. Secara umum, penggunaan verba causative bertujuan membuat pihak tertentu melakukan sesuatu, seperti dalam contoh berikut:

The trainers for the seminar had crews (move) their equipment to the conference center.

The president had her travel agent (make) the reservations.

The ship's captain requests that all passengers (review) emergency procedures.

The manager got his staff (to work) last weekend.

Kecuali pada contoh keempat, ketiga kalimat lainnya menggunakan verba bentuk dasar. Pada kalimat ketiga request berperan sebagai verba causative. Penggunaan verba causative get diikuti verba dalam bentuk to + infinitive. Dari contoh tersebut terlihat bahwa hanya verba causative yang mengalami infleksi (kontekstual) sesuai tense, sedangkan verba yang mengikuti selalu berbentuk dasar atau to + infinitive.

Phrasal verb terdiri dari dua atau lebih kata, biasanya berupa verba dan preposisi, yang dapat berfungsi sebagai predikat (verb) dalam kalimat bahasa Inggris, sehingga sulit untuk diklasifikasikan hanya sebagai verba. Phrasal verb biasanya mempunyai makna yang berbeda dari makna masing-masing konstituen pembentuknya, seperti contoh berikut:

Though the amount of money you spend in the year will be identical, your higher bills will be (spread out) throughout the year.

We need about 200 door prizes to hand (out) at the banquet.

Meskipun termasuk dalam kata kerja bantu, permasalahan yang umum dijumpai pada soal yang melibatkan modal justru bukan pada modal tersebut, melainkan pada verba yang mengikuti, seperti dalam kalimat Using fans or heaters in the office should not (be) necessary. Setelah modal (will, must, can, may, dan lain-lain), verba atau kata kerja bantu berikutnya harus dalam bentuk dasar. Selain itu, beberapa modal terdiri dari dua atau lebih kata (misal, have to dan be going to). Verba bentuk dasar digunakan pula dalam kalimat yang mempunyai maksud memberi saran/instruksi/perintah, seperti dalam kalimat "When you need supplies, (file) a request with the office manager." Kalimat imperatif biasanya mempunyai subjek implisit you/we, [... (Ø: you) file a request ...]. Karena bertujuan memberi saran/instruksi/perintah, kalimat imperatif akan selalu menggunakan present tense.

Fungsi gerund dalam kalimat lebih mirip nomina dibanding verba. Apabila terdapat dua atau lebih verba yang berurutan, verba kedua dan seterusnya harus berupa gerund atau bentuk to + infinitive, apapun tense kalimat tersebut. Lebih lanjut, verba yang mengikuti phrasal verb harus selalu berupa gerund, karena bentuk gerund selalu digunakan setelah preposisi, seperti dalam kalimat "The manager suggested (organizing) a research team." 
Gerund di sini berfungsi sebagai konstituen (embedded clause) yang biasa diisi oleh nomina, karena organizing a research team bisa digantikan dengan pronomina $i t$.

Terkait embedded clause, permasalahan terkait relative pronoun tidak dapat dikategorikan dalam conjunction, contohnya kalimat "By the time you have finished with your coursework, you will feel (that) you have accomplished something." Kalimat ini terdiri dari tiga klausa: by the time you have finished with your coursework, you will feel, dan you have accomplished something. Relative clause pada bagian ketiga merupakan fused relative construction (Huddleston dan Pullum 2002:63), dan membutuhkan relative pronoun yang sesuai. Berbeda dengan relative construction lain seperti tipe integrated dan supplementary, tipe fused lebih mirip dengan frasa nomina; dalam contoh ini klausa ketiga dapat diganti dengan pronomina it. Hal ini dapat menimbulkan kendala tersendiri terkait pemilihan relative pronoun yang sesuai (dalam contoh ini that).

\section{Pencarian Detail, Penarikan Kesimpulan, dan Hubungan Antarkalimat}

Berdasarkan klasifikasi Fauziati (2016:21), seperti yang telah disebutkan dalam pendahuluan, pertanyaan pada bagian Reading Comprehension berkisar pada gagasan utama, informasi yang secara langsung dinyatakan, informasi yang tersirat, tujuan penulis, dan bagaimana penulis mengembangkan dan menyajikan bacaan. Namun dalam TOEIC score report hanya tercantum tiga yang terkait erat dengan bagian ini, yang meliputi pencarian detail, penarikan kesimpulan, dan hubungan antarkalimat. Di sini pembahasan akan lebih condong pada klasifikasi versi ETS, untuk kemudian dihubungkan dengan klasifikasi yang melibatkan lima kategori.

Kemampuan terkait pencarian detail, penarikan kesimpulan, dan hubungan antarkalimat erat hubungannya dengan bagian Reading Comprehension (Part 7). Secara umum, kemampuan yang paling kurang terdapat pada penarikan kesimpulan, disusul pencarian keterkaitan dan detail, dengan persentase yang sangat kecil dibanding dua kemampuan lain. Tabel 3-2 merangkum jumlah soal dengan persentase jawaban benar yang rendah dalam Reading Comprehension terkait ketiga kemampuan tersebut.

Tabel 3-2. Distribusi Frekuensi Jumlah Soal Berdasarkan Kemampuan yang Diukur

\begin{tabular}{lccc}
\hline \multicolumn{1}{c}{ Kemampuan } & UAS Bahasa Inggris I & UTS Bahasa Inggris II & UAS Bahasa Inggris II \\
Detail (3) & $1(41,46 \%)$ & $1(43,28 \%)$ & $1(43,33 \%)$ \\
Penyimpulan (23) & $7(14,24-44,62 \%)$ & $10(26,89-46,22 \%)$ & $6(19,63-49,26 \%)$ \\
Keterhubungan (12) & $2(34,81-35,13 \%)$ & $9(31,51-46,64 \%)$ & $1(41,85 \%)$ \\
\hline
\end{tabular}

Keterangan: angka dalam kurung menunjukkan persentase siswa dengan jawaban benar

Pada bagian ini terdapat teks berupa artikel, surat, formulir, faks, memo, tabel, bagan, pemberitahuan, instruksi, iklan, dan instruksi. Membaca cepat menjadi penting terutama di bagian ini karena dalam keseluruhan Reading Section terdapat 100 soal yang harus dikerjakan hanya dalam waktu 75 menit. Kunci membaca cepat adalah mengetahui informasi yang harus ditemukan. Oleh sebab itu, disarankan untuk membaca pertanyaan terlebih dahulu sebelum soal. Tabel 3-3 menunjukkan jumlah soal dengan persentase jawaban benar yang rendah dalam Reading Comprehension terkait kata tanya yang digunakan.

Tabel 3-3. Distribusi Frekuensi Jumlah Soal Berdasarkan Kata Tanya

\begin{tabular}{lccc}
\hline Kata Tanya & UAS Bahasa Inggris I & UTS Bahasa Inggris II & UAS Bahasa Inggris II \\
What $(16)$ & $2(34,81-35,13 \%)$ & $8(26,89-46,64 \%)$ & $6(19,63-49,26 \%)$ \\
Which $(8)$ & $4(14,24-29,11 \%)$ & $3(40,76-44,54 \%)$ & $1(34,44 \%)$ \\
How $(5)$ & $2(39,56-41,46 \%)$ & $2(44,54-46,22 \%)$ & $1(41,85 \%)$ \\
\hline
\end{tabular}

40 | Satriya Bayu A., et al: Pemanfaatan Moodle Pada Identifikasi Kendala... 


\begin{tabular}{lccc}
\hline Why $(4)$ & - & $4(32,35-43,28 \%)$ & - \\
Who $(3)$ & $1(24,05 \%)$ & $2(40,34-44,12 \%)$ & - \\
Whom $(1)$ & $1(44,62 \%)$ & - & - \\
When $(1)$ & - & $1(36,55 \%)$ & \\
\hline
\end{tabular}

Tiap kata tanya dapat melibatkan kemampuan penarikan kesimpulan, pencarian hubungan atau detail, meskipun terdapat kecenderungan pada which, yang mempunyai kecenderungan lebih pada penarikan kesimpulan (inference), seperti tampak dalam tabel 3-4.

Tabel 3-4. Hubungan antara Kemampuan yang Diukur dengan Kata Tanya

\begin{tabular}{lccc}
\hline Kata Tanya & Detail & Penyimpulan & Keterhubungan \\
What $(16)$ & $1(43,33 \%)$ & $8(26,89-49,26 \%)$ & $7(31,51-46,64 \%)$ \\
Which $(8)$ & - & $7(14,24-44,54 \%)$ & $1(41,18 \%)$ \\
How $(5)$ & $1(41,46 \%)$ & $2(39,56-46,22 \%)$ & $2(41,85-44,54 \%)$ \\
Why $(4)$ & $1(43,28 \%)$ & $2(32,35-41,6 \%)$ & $1(34,45 \%)$ \\
Who $(3)$ & - & $2(24,05-44,12 \%)$ & $1(40,34 \%)$ \\
Whom $(1)$ & - & $1(44,62 \%)$ & - \\
When $(1)$ & - & $1(36,55 \%)$ & - \\
\hline Keterangan: angka dalam kurung menunjukkan persentase siswa dengan jawaban benar
\end{tabular}

Terdapat tiga soal dengan persentase rendah terkait kemampuan pencarian detail, yang melibatkan what, how, dan why. Berikut pertanyaan beserta pilihan jawaban yang tertulis

Question: According to the article, eco-travelers should expect ...

Answer: to hear lectures on the environment

Question: How is Nin Go cooked?

Answer: It is steamed.

Question: Why won't Stuart send the May invoice to Karen Electric's temporary address?

Answer: The bill has already been paid.

Jawaban dari ketiga contoh pertanyaan tersebut sama persis dengan yang tercantum dalam teks yang menyertai. Dalam teks artikel yang tersedia bersama soal what tercantum "The tourists on these trips are given lectures on the effects of the loss of our planet's natural wonders." Pada teks instruksi cara pembuatan yang disertakan dalam soal how tertulis Steam for 40-50 minutes, ... Pada teks yang disertakan dalam soal why, dalam salah satu bagian surat pemberitahuan, tertulis "In fact, we owe you a refund for May because you paid for the order in advance."

Seperti telah disebutkan sebelumnya bahwa terdapat kecenderungan antara kata tanya which dengan kemampuan penarikan kesimpulan. Pada salah satu soal terdapat pertanyaan "Which of the following vacation periods requires a supervisor's approval?" dan dalam salah satu bagian surel tertulis "Supervisors must approve any and all vacation periods longer than one week". Berbeda dengan contoh sebelumnya terkait detail, dalam pilihan tidak tercantum longer than one week, sehingga diperlukan kemampuan penarikan kesimpulan. Komunikasi (verbal) melibatkan pemrosesan kode dan proses inferensi (Sperber dan Wilson, 1995:3).

Kemampuan ketiga terkait Reading Comprehension, pencarian hubungan antar kalimat, terlihat dalam kalimat “What is the deadline for Marcus to apply for early retirement?” Pada surat pemberitahuan pertama, yang dicantumkan bersama soal, tertulis "Interested employees should apply by September 1, 20__. Supervisors with twenty years or more of employment at this company have an extra two months to apply." Kalimat kedua petikan 
dari surat ini menjadi kunci dalam menjawab soal. Pertama, terdapat perpanjangan waktu bagi jabatan supervisor. Kedua, kata supervisor menghubungkan surat pertama dengan surat kedua. Repetisi dapat berperan dalam kohesi teks, dalam hal ini berupa kohesi leksikal. Interpretasi dari suatu kata cenderung akan merujuk pada kata yang sama yang muncul terlebih dahulu (Halliday dan Hasan, 1976:12). Dari sini jelas bahwa tambahan waktu tersebut berlaku karena pada surel berikutnya tertulis "He is a supervisor with twenty years of experience at this company."

Dari uraian di atas tampak bahwa pembagian kemampuan menjadi tiga kelompok lebih tepat, karena tidak terjadi tumpang tindih. Pada klasifikasi dengan lima kategori terdapat tumpang tindih antara kemampuan identifikasi gagasan utama, informasi yang tersirat, dan tujuan penulis. Permasalahan ini tidak ditemui dalam klasifikasi dengan tiga kelompok, karena ketiganya masuk dalam kemampuan penarikan kesimpulan. Pembagian konteks bacaan menjadi General Business, Manufacturing, Finance and Budgeting, Offices, Personnel, Purchasing, Housing/corporate property, Travel, Dining out, Entertainment, dan Health pun tidak memberi manfaat apapun terkait strategi yang diperlukan untuk menghadapi tiap konteks.

\section{Kosa Kata}

Perbendaharaan kata berkaitan erat dengan part 5, 6, dan 7 Reading Section. Terdapat 11 soal dengan persentase jawaban rendah terkait kosa kata [6 pada UAS bahasa Inggris I (33,54-40,19 \% siswa dengan jawaban benar), 1 pada UTS bahasa Inggris II (36,55 \% siswa dengan jawaban benar), dan 4 pada UAS bahasa Inggris II (40-44,81 $\%$ siswa dengan jawaban benar)]. Bentuk soal tipe ini dapat melibatkan pilihan jawaban yang mirip secara penulisan, seperti dalam contoh berikut.

Lucia has finally ... the position she always wanted.
A. attained
B. attended
C. attired
D. attuned

Pada contoh berikut kemiripan terdapat pada makna, sehingga perlu diperhatikan konteks, baik terkait kata-kata lain yang muncul maupun penggunaan, untuk sampai pada jawaban yang tepat (enhance).

Flowers create a positive image at corporate events and can (41...) the attractiveness of your company's products during promotions.
A. enhance
B. add
C. rise
D. gain

Konteks juga penting untuk diperhatikan dalam Reading Comprehension. Pada bagian ini terdapat lebih banyak kata yang muncul, yang bisa jadi membantu atau justru malah mengecoh, seperti dalam pertanyaan "The word abolished is closest in meaning to...." Pada contoh tersebut petikan artikel memberi gambaran penggunaan istilah abolished, "That regulation has been abolished and has opened the ports to ships from around the world," meskipun tidak secara spesifik menunjukkan jawabannya. Seluruh pertanyaan yang menjadi kendala dalam Reading Comprehension yang berhubungan dengan kosa kata berkaitan dengan sinonim.

\section{KESIMPULAN}

42 | Satriya Bayu A., et al: Pemanfaatan Moodle Pada Identifikasi Kendala... 
Penggunaan e-learning berbasis Moodle dalam bentuk kuis daring mampu mempermudah identifikasi kendala yang dihadapi peserta dalam mengerjakan soal reading dengan format tes TOEIC. Berdasarkan analisis data yang diperoleh, klasifikasi kemampuan, yang terdiri dari kemampuan terkait kosa kata, tata bahasa, pencarian detail, penarikan kesimpulan, dan hubungan antarkalimat, terbukti lebih tepat. Lebih lanjut, selain tense, part of speech, conjunction, comparatives, dan conditionals, klasifikasi dalam kemampuan tata bahasa juga harus mencakup konstruksi pasif, participle, causative, phrasal verb, modals, kalimat imperatif, gerund, dan relative pronoun. Selain itu klasifikasi teks dalam Reading Comprehension berdasarkan konteks bacaan tidak teridentifikasi mempunyai pengaruh terhadap strategi pengerjaan.

Kesulitan yang berhubungan dengan tata bahasa terkait erat dengan Text Completion dan, terutama, Incomplete Text. Kesulitan yang berhubungan dengan pencarian detail, penarikan kesimpulan, dan hubungan antarkalimat erat hubungannya dengan Reading Comprehension. Kesulitan yang berhubungan kosa kata tersebar di seluruh Reading Section. Dari kelima kemampuan ini, yang teridentifikasi paling kurang adalah tata bahasa, sedangkan pencarian detail menduduki peringkat tertinggi. Pencarian detail merupakan kemampuan yang relatif sehari-hari lebih banyak digunakan dibanding tata bahasa. Hal Ini bisa jadi merupakan indikasi bahwa tingkat pengenalan mahasiswa terhadap format tes TOEIC, dalam hal ini Reading Section, masih rendah.

Untuk mengatasi kendala ini disarankan untuk menambah jumlah bank soal daring. Hal ini berkaitan dengan efek washback tes terhadap pengajaran. Bank soal juga diharapkan mampu memberi gambaran yang lebih nyata kepada siswa mengenai soal-soal yang akan dihadapi sehingga motivasi siswa untuk belajar akan meningkat. Selain itu, seperti telah disebutkan sebelumnya, terdapat beberapa kelebihan yang dimiliki kuis dan bank soal daring yang tidak dimiliki versi cetak.

\section{DAFTAR PUSTAKA}

Brown, J.D. (2004). Research Methods for Applied Linguistics: Scope, Characteristics, and Standards. Dalam

Davies, A. \& C. Elder (ed.), The Handbook of Applied Linguistics (pp. 476-500). Malden: Blackwell Publishing Ltd.

Davies, A. \& C. Elder (ed.). (2004). The Handbook of Applied Linguistics. Malden: Blackwell Publishing Ltd.

Halliday, M.A.K. \& R. Hasan. (1976). Cohession in English. London: Longman Group Limited.

Huddleston, R. \& G.K. Pullum. (2002). The Cambridge Grammar of the English Language. Cambridge: Cambridge University Press.

Lougheed, L. (2006). Barron's TOEIC Test (4 ${ }^{\text {th }}$ Edition). New York: Barron's Educational Series, Incorporated. Rogers, B. (2006). Complete Guide to the TOEIC Test: Student Book ( $3^{\text {rd }}$ Edition). Boston: Heinle, Cengage Learning.

Sinclair, J. (1991). Corpus, Concordance, Collocation. Oxford: Oxford University Press.

Sperber, D. \& D. Wilson. (1995). Relevance: Communication and Cognition (Second Edition). Oxford: Blackwell Publishers Limited.

Darmaliana \& E. Yeny. (2016). Negative and Positive Effect of Backwash on TOEIC Test. HOLISTICS, 8(15), 24-29.

Fauziati, E. (2016). Analisis Pertanyaan pada Butir Soal Reading Comprehension pada Test TOEIC. Jurnal Penelitian Humaniora, 17(1), 9-22. 
Harahap, S.H. 2015. Pemanfaatan E-Learning Berbasis LCMS Moodle sebagai Media Pembelajaran untuk Mata Kuliah Sistem Informasi Akuntansi. Jurnal Riset Akuntansi dan Bisnis, 15(1), 86-99.

Sulisworo, D., et al. 2016. Cooperative-blended learning using Moodle as an open source learning platform. International Journal of Technology Enhanced Learning, 8(2), 187-198.

Surjono, H.D., 2014. The Evaluation of a Moodle Based Adaptive e-Learning System. International Journal of Information and Education Technology, 4(1). 89-92.

44 | Satriya Bayu A., et al: Pemanfaatan Moodle Pada Identifikasi Kendala... 